\title{
Acalypha wilkesiana Muell Arg Induced Diuresis in Salt-Loaded Rats: Implications for the Management of Edema, Obesity and Hypertension
}

\section{IKEWUCHI, CHIGOZIE JUDE*; IKEWUCHI, CHIDINMA CATHERINE; ONWUKA, CHUKWUMA FRANCIS}

\author{
Department of Biochemistry, Faculty of Science, University of Port Harcourt, P.M.B. 5323, Port Harcourt, Nigeria. \\ *Corresponding author (e-mail: ecoli240733@yahoo.com,Tel: +2348033715662)
}

\begin{abstract}
Effect of the leaves on the weight, urine output, and plasma and urine chemistry of salt-loaded rats was investigated. The control group received a diet consisting $100 \%$ of the commercial feed; the test-control received a diet consisting $8 \%$ salt and $92 \%$ commercial feed, while the test received diet containing $8 \%$ salt, $5 \%$ leaf powder and $87 \%$ commercial feed. There was no significant difference in the food intake of the three groups, although the weight change of the test animals was significantly lower $(\mathrm{p}<0.05)$ than the other two groups. The time course of the mean daily urine output per rat revealed an initial diuretic impact of the leaves, to a level that was sustained through to the sixth week, while there was a gradual/steady increase in the urine output of the test-control. There was no significant difference in the plasma acetone, albumin and creatinine concentrations of the test and test-control, while the plasma sugar concentration of the test was significantly $(p<0.05)$ the least. The leaves had no effect on urinary excretion of acetone, potassium and creatinine, but significantly lowered $(\mathrm{p}<0.05)$ the albumin and increased the sodium excretion.@JASEM
\end{abstract}

Acalypha wilkesiana Muell Arg belongs to the family Euphorbiaceae (spurge family). Its other names include $A$. amentacea and $A$. tricolor, while its common names are copperleaf, Joseph's coat, fire dragon, match-me-if-you-can. It is native to Fiji and nearby islands in the South Pacific, and is a popular outdoor plant that provides color throughout the year, although it is also grown indoors as a container plant. It is propagated by stem cuttings at any time of the year. Under ideal conditions, it grows as a spreading evergreen shrub with upright branches that tend to originate near the base and can get up to $3.1 \mathrm{~m}$ tall with a similar spread. It has leaves $(12.7-20.3 \mathrm{~cm}$ long) that are alternate, elliptic to oval, serrate and multi-colored, and small inconspicuous flowers $(10.2-20.3 \mathrm{~cm})$ that hangs in catkin-like racemes beneath the foliage. A. wilkesiana has antimicrobial properties (Ogundaini, 2005; Akinyemi et al., 2006; Oladunmoye, 2006). According to Ogundaini (2005) the expressed juice or boiled decoction is used for the treatment of gastrointestinal disorders and fungal skin infections such as Pityriasis versicolar, Impetigo contagiosa, Candida intetrigo, Tinea versicolor, Tinea corporis and Tinea pedis. In Southern Nigeria, the leaves of this plant are eaten as vegetables in the management of hypertension, consequent upon which we undertook an investigation on the effect of the plants aqueous leaf extract on plasma sodium and potassium levels of normal rabbits (Ikewuchi et al., 2008). In the present study, we investigated the effect of the leaves on the weight, urine output, plasma and urine chemistry of salt-loaded rats.

\section{MATERIALS AND METHODS}

Procurement of Experimental Animals and Feed: Albino rats were collected from the animal house of the Pathology Department of Lagos University Teaching Hospital (LUTH), Lagos, Nigeria. The feed used is Guinea grower's marsh from Bendel Feed and Flour Mill Limited, Ewu, Nigeria.

Collection of Leaves: The leaves were collected from within Hall 1 of the Ugbowo Campus of the University of Benin, Benin City, Nigeria. After due identification at the Department of Plant Science and Biotechnology, Faculty of Life sciences, University of Benin, Benin City, Nigeria, they were rid of dirt, oven dried and ground into powder and used for compounding the test diet.

Experimental Design and Composition of Diet: The rats were randomly sorted into three groups of five animals each, so that the average weight difference was $\pm 1.3 \mathrm{~g}$. The animals were individually housed in plastic metabolic cages. After a three-day acclimatization period, the treatment commenced and lasted for 6 weeks. The control group received a diet consisting $100 \%$ of the commercial feed; the testcontrol received a diet consisting $8 \%$ salt and $92 \%$ commercial feed, while the test received diet containing $8 \%$ salt, 5\% leaf powder and $87 \%$ commercial feed. The $8 \%$ salt-loading was adopted from Obiefuna et al. (1991). The animals were allowed food and water ad libitum. The daily food intake, urine and fecal output, and weekly weight changes were recorded. The urine samples were collected and analyzed. At the end of the treatment period the animals were fasted overnight after which they were painlessly sacrificed by decapitation under chloroform anesthesia, and their blood collected into heparin sample bottles. 


\section{Determination of Plasma and Urinary Chemistry:}

- Plasma and urinary protein assays were carried out as reported by Lowry et al. (1951). $0.5 \mathrm{~mL}$ of the test sample was mixed with $5 \mathrm{~mL}$ of alkaline protein reagent, and incubated at in a water bath at $25^{\circ} \mathrm{C}$, for $15 \mathrm{~min}$, after which $0.5 \mathrm{~mL}$ of FolinCiocalteau reagent was added and absorbance was read after $30 \mathrm{~min}$, at $750 \mathrm{~nm}$.

- The determination of creatinine in both urine and blood was carried out by the method of Folin as reported by Singh (1990). $2 \mathrm{~mL}$ of the test sample was mixed with $2.5 \mathrm{~mL}$ of picric acid reagent, incubated in a water bath at $27^{\circ} \mathrm{C}$, for $30 \mathrm{~min}$, and the absorbance was read at $510 \mathrm{~nm}$.

- Plasma and urinary acetone were estimated by the method of Nadeau (1952). $0.2 \mathrm{~mL}$ of the test sample was mixed with $2 \mathrm{~mL}$ of vanillin reagent, incubated in a water bath at $55^{\circ} \mathrm{C}$, for $1 \mathrm{hr}$, before reading the absorbance at $415 \mathrm{~nm}$.

- Urinary sodium and potassium were determined by flame photometry at the Chemical Pathology Department of University of Benin Teaching Hospital (UBTH), Benin City, Nigeria.

- The plasma glucose or reducing sugar content was determined by the method of Somogyi as reported by Plummer (1978). $1 \mathrm{~mL}$ of the test sample was mixed with $1 \mathrm{~mL}$ of Somogyi reagent $\mathrm{D}$, and incubated at in a water bath at $100^{\circ} \mathrm{C}$, for $10 \mathrm{~min}$, after which the mixture was cooled, and $2 \mathrm{~mL}$ of Somogyi reagent $\mathrm{C}$ was added. The resultant solution was allowed to stand for $10 \mathrm{~min}$, after which it was diluted with $10 \mathrm{~mL}$ of distilled water before reading the absorbance at $510 \mathrm{~nm}$. All the reagents used were of analytical grade.

Statistical Analysis of Data: All values are quoted as the mean $\pm \mathrm{SD}$. The values of the various parameters for the control, test control and test groups were analyzed for statistical significant differences using the student's t-test. Means which differ significantly at $p=0.05$, were assumed to be significantly different.

\section{RESULTS AND DISCUSSION}

The effect of Acalypha wilkesiana on feed intake, feed efficiency, urine output and weight changes of salt-loaded rats, is shown in Table 1. There was no significant difference in the food intake of the three groups, however, the weight change of the test animals was significantly lower $(\mathrm{p}<0.05)$ than the other two groups. Weight reduction is one of the means of alleviating coronary risk incidence, diabetes mellitus, dyslipidemia, hypertension, obesity and physical functioning (Trussell et al., 2005; Krauss et al., 2006), and is one of the strategies for increasing low HDL-C levels (Assmann and Gotto, 2004), as well as improving as well as the insulin resistance (Krauss et al., 2006). In this study, a significantly lower mean daily weight gain was observed in the test animals, thus supporting the use of the plant's leaf in the management of hypertension, as well as suggesting its use in the management of obesity and dyslipidemia. The plant leaves significantly lowered and increased $(p<0.05)$ the feed efficiency ratio and feed conversion ratio respectively. There was no significant difference in the daily mean daily urine output of the test and test -control, both of which were significantly higher $(p<0.05)$ than that of the control. However, the time course of the mean daily urine output per rat (Table 2) revealed an initial diuretic impact of the leaves, to a level that was sustained through to the sixth week, while there was a gradual/steady increase in the urine output of the test-control. This increased continued with time and even overshot the test group. This increase may be due to increase in glomerular filtration rate induced by the salt load (De Wardener and MacGregor, 2002). The sustained diuretic effect of the leaves may have accounted for the significantly reduced weight gain in the test animals, since according to Freis et al. (1988), diuresis leads to weight loss which is in actual sense an index of volume loss and correlates with reduction in blood pressure.

Table 1: The effect of Acalypha wilkesiana on feed intake, weight changes, feed efficiency ratio, feed conversion ratio and urine output of salt-loaded rats

\begin{tabular}{lcll}
\hline Parameter & \multicolumn{3}{c}{ Value } \\
Normal & \multicolumn{2}{c}{ Test-control } & \multicolumn{2}{c}{ Treated } & \\
Feed intake (g/rat/day) & $18.600 \pm 0.400^{\mathrm{a}}$ & $19.100 \pm 0.100^{\mathrm{a}}$ & $18.900 \pm 0.500^{\mathrm{a}}$ \\
Weight gain (g/rat/day) & $1.730 \pm 0.330^{\mathrm{a}}$ & $1.900 \pm 0.180^{\mathrm{a}}$ & $0.920 \pm 0.570^{\mathrm{b}}$ \\
Feed efficiency ratio & $0.093 \pm 0.018^{\mathrm{a}}$ & $0.101 \pm 0.009^{\mathrm{a}}$ & $0.049 \pm 0.049^{\mathrm{b}}$ \\
Feed conversion ratio & $10.751 \pm 0.231^{\mathrm{a}}$ & $10.053 \pm 0.053^{\mathrm{a}}$ & $20.543 \pm 0.543^{\mathrm{b}}$ \\
Urine output (mL/rat/day) & $6.700 \pm 0.970^{\mathrm{a}}$ & $54.720 \pm 7.810^{\mathrm{b}}$ & $57.380 \pm 7.640^{\mathrm{b}}$ \\
\hline
\end{tabular}

Values are expressed as mean \pm SEM, $\mathrm{n}=5$ per group. Values within a row with the different superscripts, are significantly different at $\mathrm{p}<0.05$

* Corresponding author: Ikewuchi, Chigozie Jude 
Table 2: Time course of the effect of Acalypha wilkesiana on the urine output of salt-loaded rats

\begin{tabular}{llll}
\hline Week & \multicolumn{3}{c}{ Urine output $(\mathrm{mL} /$ rat/day) } \\
Normal & \multicolumn{2}{c}{ Test-control } & \multicolumn{2}{c}{ Treated } \\
1 & $8.50 \pm 1.44^{\mathrm{a}}$ & $21.67 \pm 6.69^{\mathrm{b}}$ & $47.43 \pm 2.94^{\mathrm{c}}$ \\
2 & $7.50 \pm 1.50^{\mathrm{a}}$ & $40.67 \pm 6.36^{\mathrm{b}}$ & $67.67 \pm 10.27^{\mathrm{c}}$ \\
3 & $5.40 \pm 0.40^{\mathrm{a}}$ & $50.40 \pm 14.11^{\mathrm{b}}$ & $65.40 \pm 6.57^{\mathrm{c}}$ \\
4 & $7.40 \pm 093^{\mathrm{a}}$ & $70.20 \pm 7.74^{\mathrm{b}}$ & $53.80 \pm 8.53^{\mathrm{c}}$ \\
5 & $7.20 \pm 0.86^{\mathrm{a}}$ & $72.40 \pm 4.21^{\mathrm{b}}$ & $62.80 \pm 8.54^{\mathrm{c}}$ \\
6 & $4.20 \pm 0.66^{\mathrm{a}}$ & $73.00 \pm 7.77^{\mathrm{b}}$ & $47.20 \pm 9.00^{\mathrm{c}}$ \\
\hline
\end{tabular}

Values are expressed as mean \pm SEM, $\mathrm{n}=5$ per group. Values within a row with the different superscripts, are significantly different at $\mathrm{p}<0.05$.

Table 3: The effect of Acalypha wilkesiana on the plasma biochemistry of salt-loaded rats

\begin{tabular}{lccc}
\hline Parameter & \multicolumn{3}{c}{ Concentration } \\
Normal & Test-control & Treated & \\
Acetone (mg/dL) & $4.30 \pm 0.10^{\mathrm{a}}$ & $5.73 \pm 0.17^{\mathrm{b}}$ & $5.73 \pm 0.73^{\mathrm{b}}$ \\
Albumin $(\mathrm{g} / \mathrm{dL})$ & $14.54 \pm 0.21^{\mathrm{a}}$ & $14.03 \pm 5.17^{\mathrm{a}}$ & $14.00 \pm 3.65^{\mathrm{a}}$ \\
Creatinine $(\mathrm{mg} / \mathrm{dL})$ & $38.80 \pm 16.80^{\mathrm{a}}$ & $111.13 \pm 44.43^{\mathrm{b}}$ & $103.67 \pm 70.37^{\mathrm{b}}$ \\
Sugar $(\mathrm{mg} / \mathrm{dL})$ & $354.00 \pm 21.00^{\mathrm{a}}$ & $392.33 \pm 41.35^{\mathrm{a}}$ & $257.00 \pm 85.45^{\mathrm{b}}$ \\
\hline
\end{tabular}

Values are expressed as mean \pm SEM, $n=5$ per group. Values within a row with the different superscripts, are significantly different at $\mathrm{p}<0.05$.

Table 4: The effect of Acalypha wilkesiana on the urine chemistry of salt-loaded rats

\begin{tabular}{lccl}
\hline Parameter & \multicolumn{3}{c}{ Output (mg/24hr) } \\
Normal & Test-control & Treated \\
\hline Acetone & $1.49 \pm 0.11^{\mathrm{a}}$ & $3.39 \pm 0.36^{\mathrm{b}}$ & $3.70 \pm 0.66^{\mathrm{b}}$ \\
Albumin & $36.76 \pm 14.04^{\mathrm{a}}$ & $358.76 \pm 59.42^{\mathrm{b}}$ & $196.58 \pm 51.94^{\mathrm{c}}$ \\
Creatinine & $2.06 \pm 0.27^{\mathrm{a}}$ & $6.17 \pm 1.10^{\mathrm{b}}$ & $8.66 \pm 2.21^{\mathrm{b}}$ \\
Sodium & $6.50 \pm 0.70^{\mathrm{a}}$ & $40.1 \pm 6.80^{\mathrm{b}}$ & $49.1 \pm 1.70^{\mathrm{c}}$ \\
Potassium & $8.50 \pm 1.40^{\mathrm{a}}$ & $9.60 \pm 1.40^{\mathrm{a}}$ & $8.90 \pm 0.30^{\mathrm{a}}$
\end{tabular}

Values are expressed as mean \pm SEM, $n=5$ per group. Values within a row with the different superscripts, are significantly different at $\mathrm{p}<0.05$

The effect of the leaves on the plasma parameters of salt-loaded rats is shown in Table 3. There was no significant difference in the plasma acetone, albumin and creatinine concentrations of the test and testcontrol, while the plasma sugar concentration of the test was significantly lower $(p<0.05)$ than those of the control and test control. This indicates that the leaf may probably have hypoglycemic effect. Use of diuretics has not been associated with increased serum creatinine levels in the absence of volume depletion (Salive et al., 1995).

The effect of leaves on urine parameters of saltloaded rats is given in Table 4. There were no significant differences in the urinary excretion of acetone, potassium and creatinine. The level of albumin excreted by the test group is significantly lower than that of the test control, but significantly higher $(p<0.05)$ than that of the control. The level of sodium excreted by the test animals is significantly higher $(\mathrm{p}<0.05)$ than those of the test control and control.

Finally, our result supports the use of Acalypha wilkesiana leaves in the management of hypertension, as well as unveiling its likely usage in the management of edema and obesity.

\section{REFERENCES}

Akinyemi KO, OK Oluwa, and EO Omomigbehin, 2006. Antimicrobial activity of crude extracts of three medicinal plants used in south-western Nigerian folk medicine on some food borne bacterial pathogens. Afr J Trad CAM, 3(4): 1322.

Assmann, G; Gotto, AM Jr. (2004). HDL Cholesterol and Protective Factors in Atherosclerosis. Circulation, 109[suppl III]:III-8-III-14.

De Wardener, HE; MacGregor, GA (2002). Harmful effect of dietary salt in addition to hypertension. J Hum Hypertens, 16(4): 213-223.

Freis, ED; Reda, DJ; Materson, BJ (1988). Volume (weight) loss and blood pressure following thiazide diuretics. Hypertension, 12: 244-250.

Ikewuchi, JC; Anyadiegwu, A; Ugono, EY; Okungbowa, SO (2008). Effect of Acalypha wilkesiana Muell. Arg. on Plasma Sodium and Potassium Concentration of Normal Rabbits. Pak J Nutr, 7(1): 130-132. 
Krauss, RM; Blanche, PJ; Rawlings, RS; Fernstrom, HS; Williams, PT (2006). Separate effects of reduced carbohydrate intake and weight loss on atherogenic dyslipidemia. Am J Clin Nutr, 83(6):1025-1031.

Lowry, OH; Rosebrough, NJ; Farr, Al; Randall, RJ (1951). Protein determination with the Folin phenol reagent. J Biol Chem, 193: 265-275.

Nadeau, G (1952). Determination of acetone plus acetoacetic acid in blood or serum. Can Med Assoc J, 67: 158.

Obiefuna, PCM; Sofola, OA; Ebeigbe, AB (1991). Dietary salt-loading attenuates endothelium dependent relaxation in response to histamine but not to acetylcholine in rat aortic rings. Exptl Physiol, 76: 135-138.

Ogundaini, AO (2005). From Greens Into Medicine: Taking a Lead From Nature. An Inaugural Lecture Delivered at Oduduwa Hall, Obafemi Awolowo University, Ile-Ife, Nigeria. Inaugural Lecture Series 176. OAU Press Limited, Ile-Ife, Nigeria, pp: 12-15.
Oladunmoye, MK (2006). Comparative Evaluation of Antimicrobial Activities and Phytochemical Screening of Two Varieties of Acalypha wilkesiana. Intern J Tropical Med, 1(3): 1348136.

Plummer DT, 1978. An Introduction to Practical Biochemistry, $2^{\text {nd }}$ edition. McGraw-Hill: London.

Salive, ME; Guralnik, JM; Pahor, M; Jones, C; Agodoa, L; Wallace, RB (1995). Serum creatinine levels in older adults: relationship with health status and medications. http://findarticles.com/p/articles/mi_m2459/is_n 2_v24/ai_16999738/pg_1

Singh SP, 1990. Practical Manual of Biochemistry, $2^{\text {nd }}$ edition. CBS Publishers: Delhi. pp: 164-166.

Trussell, KC; Hinnen, D; Gray, P; Drake-Nisly, SA; Bratcher, KM; Ramsey, H; Early, J (2005). Case Study: Weight Loss Leads to Cost Savings and Improvement in Metabolic Syndrome. Diabetes Spectrum, 18(2): 77-79. 